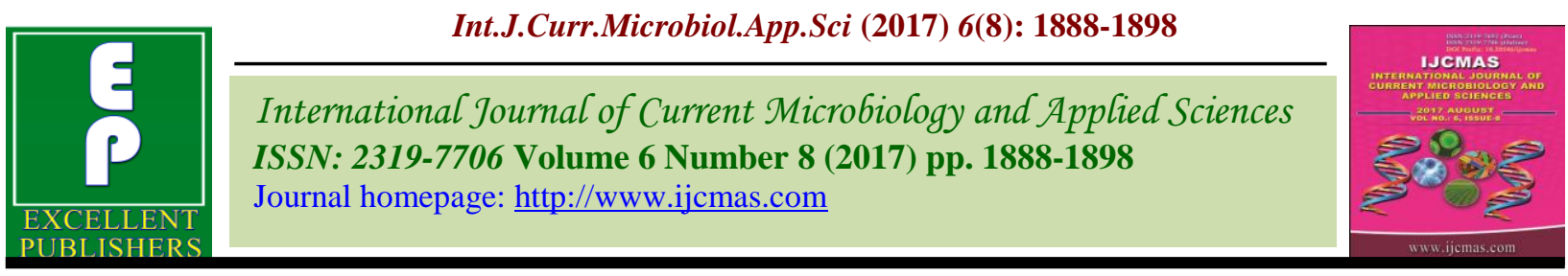

Original Research Article

https://doi.org/10.20546/ijcmas.2017.608.223

\title{
Induced Resistance in Potato against Early Blight Caused by Alternaria solani (Sorauer) Through Plant Extracts as Inducer
}

\author{
Virendra Kumar*, S.K. Biswas, Kishan Lal, Devash Nagar and V. Tilak Chowdary \\ Department of Plant Pathology C.S.A.U.A. \& T., Kanpur-208002, India \\ *Corresponding author
}

A B S T R A C T

\begin{tabular}{|c|}
\hline Keywords \\
\hline $\begin{array}{l}\text { Induced } \\
\text { resistance, } \\
\text { Alternaria solani, } \\
\text { Potato, Lantana } \\
\text { camara, Plant } \\
\text { extracts. }\end{array}$ \\
\hline Article Info \\
\hline $\begin{array}{l}\text { Accepted: } \\
\text { 19 June } 2017 \\
\text { Available Online: } \\
10 \text { August } 2017\end{array}$ \\
\hline
\end{tabular}

Pre-foliar spray with Parthenium hysterophorus, Lantana camara, Physalis, Melilotus albus, Datura stramonium, Solanum nigrum, Achyranthus aspera, Salix sp., Thevetia peruviana, Durenta erecta Polyanthia longifolia followed by challenge inoculation by Alternaria solani showed that among the treatment, Lantana camara treated plant representing minimum disease severity as $1.50,5.33$ and $8.12 \%$ at 2,6 and 10 days of challenge inoculation. The potato plant treated with plant extracts as inducers sensitized to produce increased level of soluble protein and total phenol contents. The maximum increase of soluble protein content was found in Lantana camara treated potato leaves indicating $34.05,36.65,36.85$ and $36.25 \mathrm{mg} / \mathrm{g}$ of fresh leaves against 18.33, 20.3520 .55 and $20.65 \mathrm{mg} / \mathrm{g}$ in case of control at 2, 4, 6 and 8 days of pathogen inoculation. Similarly, total phenol content was also found to be maximum in Lantana camara treated plant, representing $2.65 \mathrm{mg} / \mathrm{g}, 3.17 \mathrm{mg} / \mathrm{g}, 3.27 \mathrm{mg} / \mathrm{g}$ and $3.35 \mathrm{mg} / \mathrm{g}$ of fresh leaves at 2, 4, 6 and 8 days of pathogen inoculation. Correlation coefficient analysis revealed that there was negative correlation $(\mathrm{r}=-0.3074,-0.2560$ and -0.2563$)$ between disease severity and soluble protein content at 2, 6 and 10 days of treatment. Similarly, total phenol content also showed negative correlation $(\mathrm{r}=-0.1591,-0.5608$ and -0.5495$)$ with disease severity. It is therefore, suggested that, protection of potato plants against $A$. solani by Plant extracts as inducer might be due to stimulation of plants defense response.

\section{Introduction}

Early blight is caused by Alternaria solani (Sorauer) is the most destructive disease of potato in the tropical and subtropical regions with high temperature and alternating periods of dry weather and high humidity and/or irrigated potato soils, light-textured, sandy, low in organic matter (Gudmestad and Pasche, 2007). The disease can be very destructive if left uncontrolled, often resulting in complete defoliation of plants. In contrast to the name, it rarely develops early, but usually appears on mature foliage (Rowe et $a l$. , Undated). Young and middle-aged plants have low susceptibility to infection being disease influenced by the crop age. Young plants are relatively resistant, but the susceptibility increases gradually and continuously from the initiation of tuber formation so that mature plants are most susceptible to the disease (Campo et al., 2001; Johnson and Teng, 1990; Rotem, 1981; Shtienberg et al., 1996). Values in the literature for measured crop losses due to early blight vary enormously from $5-78 \%$ (Waals et al., 2004; Pasche et al., 2004, 2005). The yield losses of up to $79 \%$ have been reported in the U.S., of which $20-40 \%$ is due to seedling losses (i.e., collar rot) in the 
field. The disease can damage both potato foliage and tubers and can causes yield losses of $5-50 \%$. The pathogen is perpetuate in infected leaf or stem tissues on or anthem soil. This fungus is universally present in fields where these crops have been grown. It can also be carried on tomato seed and in potato tubers. Therefore, control of pathogen is very difficult and is challenging issue due to not only the endogenous growth of the pathogen, but also its ability to infect multiple hosts and survive for several years (Uppal et al., 2008). Management strategies of disease are mainly focused on the use of resistant hosts, chemical control and cultural practices, but are not always available or effective (Jahanshir Amini 2015, Thanassoulopoulos and Hooker, 1968). One of the potential methods of reduction of disease in plants against pathogens is the induction of plant resistance using biotics, abiotics, plant extracts an inducers (Kumar and Biswas, 2010, Kahkashan Arzoo et al., 2012, Gozzo, 2003; Malolepsza, 2006).

Induced resistance is generally characterized by the increase synthesis of chemical compound in plant that is able to prevent pathogen's growth and development. The compound may be PR-proteins, secondary metabolites in form of alkaloid, phenol, flavonoids, glycoside, phytoalexin compounds and so on (Chairul, 2003). A resistant plant has higher concentration on those chemical compounds (Agrios, 2005). Applying antagonistic fungus and bacteria in combination is one of strategies to increase plant' resistance through ISR (Induced Systemic Resistance) and there are not many researches on this strategy. Anis Rosyidah (2014) also reported that the influence of biocontrol microbes like T. viride, Streptomyces $s p$. and $P$. fluorescens on the resistance of potato crop toward Ralstonia solanacearum disease and to get increase potato growth and yield (Anis Rosyidah, 2014). Keeping the above points in view the present study was planned entitled "Induced resistance in potato against early blight caused by Alternaria solani (Soraure) through plant extracts as inducer".

\section{Materials and Methods}

The present investigation was undertaken during 2012 to 2014 at Department of Plant Pathology, C.S.A. University of Agriculture and Technology, Kanpur. The pathogen A. solani was isolated from diseased plant showing typical blight symptoms collected from Vegetable Research Farm, Chandra Shekhar Azad University of Agriculture and Technology, Kanpur, Uttar Pradesh, India.

\section{Isolation and purification of the pathogen}

A small piece of infected leaf from border of sporulating lesion along with some healthy green tissue was cut and dipped in mercuric chloride solution $(0.1 \%)$ for 30 seconds followed by rinsed in sterilized distilled water thrice and dried off with sterilized filter paper. The tissue pieces were placed at the center of Petri plate which was previously filled with Potato Dextrose Agar medium. The plates were then incubated at $18 \pm 1^{\circ} \mathrm{C}$. The Petri plates were observed daily at every $24 \mathrm{hrs}$ interval and noticed the presence of mycelium around the leave bits. As soon as the mycelia growth is noticed around the bits, the pathogen was purified by hyphal tip culture method. The fungus was observed under a compound microscope and identity of the pathogen was established on the basis of morphological and cultural characters.

\section{Collection and preparation of plant extracts as inducers}

The Plant extracts like Parthenium hysterophorus, Lantana camara, Physalis, Melilotus albus, Datura stramonium, 
Solanum nigrum, Achyranthus aspera, Salix sp., Thevetia peruviana, Durenta erecta and Polyanthia longifolia were collected from Vegetable Research Farm, Chandra Shekhar Azad University of Agriculture and Technology, Kanpur.

\section{Preparation of pathogen inoculums}

The Petri plate containing 15 days old culture of the A. solani was taken and flooded with sterile water. The mycelia along with spores were scrapped off with the help of sterile forceps and collected in a beaker. The suspension was then sieved with the help of a strainer to remove media clods. The collected spore suspension was diluted with distilled water and required concentration of spore suspension was measured with the help of a Haemocytometer.

About $250 \mu 1$ spore suspension was pipette into the counting chamber. The counting chamber of the Haemocytometer was covered with a cover slip. The Haemocytometer was further mounted over a compound microscope. Average number of spores per square was counted and the sporangial suspension was adjusted to $4.5 \times 10^{4}$ sporangia $\mathrm{ml}^{-1}$.

\section{Measurement of disease severity}

In order to ascertain the effect of inducing agents on disease development, an experiment was conducted in the wire house complex, Department of Plant Pathology with three replications for each treatment. Plants were sprayed with inducers separately at $48 \mathrm{hrs}$ before foliar inoculation with pathogen. During the course of this experiment, two controls are kept; in one case, plants were sprayed with water (Check-1) and in second case, plants were inoculated using conidial suspension of $A$. solani @ $\left(4.5 \times 10^{4}\right.$ sporangia/ml) serve as (Check-2).

\section{Artificial inoculation of pathogen}

After $48 \mathrm{hrs}$ of spraying with inducers, plants were inoculated with spore suspension of pathogen. The concentration of spore was maintained at $4.5 \times 10^{4}$ sporangia $/ \mathrm{ml}$. The conidial suspension was prepared from seven days old culture of the pathogen. The homogenized, suspension were inoculated on the foliage of each plant. The plants were then covered with polythene bags for $48 \mathrm{hrs}$ to provide suitable moisture and humidity for growth and development of the pathogen.

Observations for measuring the disease severity were taken after 2 days, 6 days and 10 days of pathogen inoculation. Disease severity was measured using a score chart consisting of 0-10 scale as described by D. K. Sahu, (2013). Ten leaves were randomly selected from the pot for measurement of disease severity.

The leaves with $1-10 \%$ infection received 1 , $11-20 \%$ infection received 2, 21-30\% infection received $3,31-40 \%$ infection received $4,41-50 \%$ infection received 5,51 $60 \%$ infection received $6,61-70 \%$ infection received $7,71-80 \%$ infection received 8,81 $90 \%$ infection received 9, 91-100\% infection received 10. Per cent disease incidence (PDI) was calculated based on the following formula.

$\mathrm{PDI}=\frac{\text { Sum of all numerical Grade }}{\text { Total No. of leaves } \times \text { Maximum Grade }} \times 100$

Biomolecules changes in potato due to effect of plant extracts as inducer during pathogenesis

The mature and fresh potato leaves were collected from different treatments and the changes in the content of soluble protein and total phenol in leaves were estimated at 2, 6, and 10 days after inoculation of the pathogen. 


\section{Estimation of soluble protein}

The method developed by Lowry et al., (1951) was used with slight modification to estimate the total soluble protein content in the leaves of each treatment. The total soluble protein content was measured by double beam UV visible spectrophotometer at $660 \mathrm{~nm}$ wave length. The content of soluble protein in leaves was express as $\mathrm{mg} / \mathrm{g}$ of fresh leave.

Potato leaves from different treatments were harvested, washed with distilled water several times and blotter dried before protein extraction. A quality of $1.0 \mathrm{gm}$ of each sample was cut into small pieces and grinded in pre-chilled pistil and mortar using 1:5 leaves: extraction buffer. The suspension was centrifuged at $10,000 \mathrm{rpm}$ for 30 minutes at $4^{\circ} \mathrm{C}$. The supernatant was collected. A quantity of $7.5 \mathrm{ml}$ of the supernatant was transferred in a tube and mixed with $2.5 \mathrm{ml}$ of sample buffer and used for protein estimation. The working standard solution was pipette out as $0.2,0.4,0.6,0.8$ and $1.0 \mathrm{ml}$ and put into series of test tubes. A quantity of 0.2, 0.4, 0.6, 0.8 and $1.0 \mathrm{ml}$ of the sample extract was also pipette out and kept into other test tubes separately. Then volumes in all the tubes were made up to $1 \mathrm{ml}$ with distilled water. A tube with $1 \mathrm{ml}$ of water served as a blank. Later on, $5 \mathrm{ml}$ of solution $\mathrm{C}$ was added in each test tube and incubated at room temperature for 10 min. Thereafter, $0.5 \mathrm{ml}$ of FCR was mixed well immediately and incubated at room temperature for $30 \mathrm{~min}$ in dark place. The absorbance at $660 \mathrm{~nm}$ against the blank was read and standard graph was drown to calculate the amount of soluble protein in sample and represented as $\mathrm{mg} / \mathrm{g}$ of fresh sample.

\section{Estimation of total phenol}

The accumulation of total phenols in potato plants after treatment with different plant extracts as inducer, followed by inoculation of pathogen was estimated following procedure developed by Bray and Thrope (1954). In this method, the total phenol estimation was carried out with FCR, which was measured at $650 \mathrm{~nm}$ wave length calorimetrically. For estimations of phenol, $1.0 \mathrm{gm}$ of leaf sample of potato was ground in a pestle and mortar in 10 times volume of $80 \%$ ethanol. It was then centrifuged to homogenate at $10,000 \mathrm{rpm}$ for 30 minutes at room temperature. Supernatant was separated and re-extracted for 5 times with required volume of $80 \%$ ethanol, centrifuged and the supernatant were pooled. It was then evaporated to dryness and residues were dissolved in $5 \mathrm{ml}$ of distilled water. Different aliquots $(0.2,0.4,0.6,0.8$ and 1.0 $\mathrm{ml})$ were pipette out into test tubes and the volume in each tube was made to $3 \mathrm{ml}$ with water. Subsequently, $0.5 \mathrm{ml}$ of FCR was added and after three minutes, $2 \mathrm{ml}$ of $20 \%$ $\mathrm{Na}_{2} \mathrm{CO}_{3}$ solution in each tube was thoroughly mixed.

Then absorbance at $650 \mathrm{~nm}$ against blank was measured using Ultra Violet Visible (UVVIS) spectrophotometer and the standard curve using different concentration of phenols was prepared. From the standard curve, the concentration of phenols in the test sample was determined and expressed as mg phenols per gm of sample materials.

\section{Results and Discussion}

\section{Effect of plant extracts as inducer on severity of early blight of potato}

The effect of tuber treatment and foliar spray with plant extracts as inducers significantly reduced disease severity of early blight of potato as compared to control-1 and control-2 in glass house condition (Table 1). Among the treatment minimum disease severity with $1.50 \%, 5.33 \%$ and $8.12 \%$ were recorded where tuber treated and sprayed with Lantana 
camara as inducers, followed by Parthenium hysterophorus as $5.50 \%, 9.55 \%$ and $12.0 \%$, Physalis as $8.28 \%, 13.0 \%$ and $15.0 \%$ at 2,6 and 10 days of pathogen inoculation, respectively. The Melilotus albus treated plants were showing $1.28 \%, 4.02 \%$ and $7.50 \%$ disease severity which are superior to control but inferior to Lantana camara, Parthenium hysterophorus and Physalis treated plant in respect to severity of disease at 2, 6 and 10 days of pathogen inoculation. From the table, it is also cleared, that all the inducers treated potato plants were showing comparatively low disease severity over control-1 and control-2. The decrease in disease severity might be due to activity of inducers which stimulate to synthesis of some defense related compounds in potato plant against $A$. solani.

The present finding was also supported by several workers as to application of biotics and abiotics inducers in induce resistance in many plants (Arzoo et al., 2012; Kumar and Biswas, 2010, Girdhari et. al., 2008). He et $a l$. , (2002) found that reduced disease severity of $F$. oxysporum f.sp. asparagi in Asparagus officinalis due to pre inoculated with nonpathogenic strains of $F$. oxysporum as inducer.

Nashwa (2012) also found that plant extracts significantly reduced the early blight disease as well as increased the yield of tomato compared to the infected control under field conditions. Nashwa S.M.A. (2012).

Biomolecule changes in association with the effect of plant extracts as inducer during pathogenesis at different days

Pre-inoculation with plant extracts change bimolecules like total soluble and protein total phenol content in plant due to effect of plant extracts as inducers were studied as pre inoculation method and changing bio- molecules were estimate at 2, 4, 6, 8 and 10 days after inoculation. The results have given as following head:

\section{Soluble protein}

The result presented in table 2 indicated that total soluble protein content in potato leaves due to application of Plant extracts as inducers ranges from $17.50-22.43 \mathrm{mg} / \mathrm{g}$ of fresh leaves. The highest content of total soluble protein was recorded from Lantana camara treated potato leaves, indicating $34.05,36.65,36.85$ and $36.25 \mathrm{mg} / \mathrm{g}$ of fresh leaves against 18.33, 20.35, 20.55 and 20.65 $\mathrm{mg} / \mathrm{g}$ in case of control-1 and 20.30, 22.25, 22.35 and $21.00 \mathrm{mg} / \mathrm{g}$ of fresh leaves in case of control-2 at 2, 4, 6 and 8 days of pathogen inoculation. The plant extracts treated potato plant possess 43.03 and 42.06 per cent increased of total soluble protein over control1 and over control-2 at 8 days of pathogen inoculation, respectively. The Parthenium hysterophorus treated potato plant showed $31.75,33.45,33.55$ and $33.69 \mathrm{mg} / \mathrm{g}$ of fresh leaves at 2, 4, 6 and 8 days of pathogen inoculation which is the second highest among the treatments, representing $38.70 \%$ over control-1 and $37.66 \%$ over control-2 at 8 days of pathogen inoculation. Among the treatment, the lowest quantity of soluble protein content was found in Melilotus albus treated potato leaves, showing 20.85, 22.30, 22.60 and $22.80 \mathrm{mg} / \mathrm{g}$ of fresh leave at 2, 4, 6 and 8 days of pathogen inoculation. From the table 2, it is also cleared that among the different days of interval, the maximum concentration of soluble protein was found at 8 days of pathogen inoculation in all the treatments, thereafter, it was declined gradually. The finding of the table showed that the application of inducing agent before application, the soluble protein content was increase in all the treatments. The highest $38.12 \%$ increased of soluble protein after application of inducing agent was recorded in 
case of Lantana camara treated plant. The increased protein content in treated plants might be responsible for defense response in plant against $A$. solani. The result presented in table 3 shows that all the treatment significantly increased the total protein content as compared to control-1 and control2 at 2, 4, 6 and 8 days of pathogen inoculation. Antoniew et al., (1980) considered that pathogen related proteins (PR protein) are involved in plant defense response to pathogens. Boller (1985) was also opined that proteins are associated with defense in plants against fungi and bacteria. Metraux et al., (1988) and Tuzun et al.,
(1989) also reported that proteins forms of chitinases and $\beta-1,3$ glucanase may be involved in the defense of plants against fungi and bacteria by their action on the cell walls of invading pathogen. The productions of chitinase and $\beta-1,3$ glucanase, which are pathogenesis related proteins (PR-proteins), have been studied most extensively. Biochemical change associated with induced resistance in crop plant against pathogens by non-conventional of chemical against have been reported by several workers (Adesh, 2008; Biswas et al., 2003; Biswas et al.,. 2012; Steiner and Schonbeack, 1995; Sindhan and Prashar, 1996).

Table.1 Effect of plant extracts as inducer on disease severity of early blight of potato at Different days of interval

\begin{tabular}{|l|c|c|c|}
\hline \multirow{2}{*}{ Name of inducer } & \multicolumn{2}{|c|}{$(\%)$} \\
\cline { 2 - 4 } & 2 Days & 6 Days & 10 Days \\
\hline Parthenium hysterophorus & 5.50 & 9.55 & 12.0 \\
\hline Lantana camara & 1.50 & 5.33 & 8.12 \\
\hline Physalis & 8.28 & 13.0 & 15.00 \\
\hline Melilotus albus & 1.28 & 4.02 & 7.50 \\
\hline Datura stramonium & 13.55 & 19.10 & 22.43 \\
\hline Solanum nigrum & 9.0 & 12.31 & 15.50 \\
\hline Achyranthus aspera & 9.19 & 10.40 & 14.0 \\
\hline Salix sp. & 9.2 & 13.10 & 17.25 \\
\hline Thevetia peruviana & 8.35 & 11.24 & 15.13 \\
\hline Durenta erecta & 8.38 & 12.23 & 16.15 \\
\hline Polyanthia longifolia & 10.15 & 14.15 & 17.10 \\
\hline Control & 36.35 & 42.50 & 55.25 \\
\hline C.D.P=(0.05) & 33.12 & 46.12 & 57.60 \\
\hline S.E (m) & 0.954 & 1.253 & 1.590 \\
\hline S.E (d) & 0.326 & 0.429 & 0.544 \\
\hline C.V. & 0.462 & 0.606 & 0.769 \\
\hline
\end{tabular}


Table.2 Effect of plant extracts as inducer on total soluble protein in potato leaves at different days of intervals after inoculation during pathogenesis ( $\mathrm{mg} / \mathrm{g}$ of fresh leaves)

\begin{tabular}{|c|c|c|c|c|c|c|c|c|c|}
\hline \multirow[t]{2}{*}{ Name of inducer } & \multicolumn{6}{|c|}{ Soluble protein content at different days of interval $(\mathrm{mg} / \mathrm{g}$ of fresh leaves) } & \multirow{2}{*}{$\begin{array}{c}\text { Percent increased over, } \\
\text { before application of } \\
\text { inducers }\end{array}$} & \multirow{2}{*}{$\begin{array}{c}\text { Percent increased over } \\
\text { control-1 } \\
\text { (at } 8 \text { days) }\end{array}$} & \multirow{2}{*}{$\begin{array}{l}\text { Percent increased } \\
\text { over control-2 } \\
\text { (at } 8 \text { days) }\end{array}$} \\
\hline & $\begin{array}{c}\text { Before application } \\
\text { of Inducers }\end{array}$ & 2 Days & 4 Days & 6 Days & 8 Days & 10 Days & & & \\
\hline Parthenium hysterophorus & 21.20 & 31.75 & 33.45 & 33.55 & 33.69 & 32.17 & 37.07 & 38.70 & 37.66 \\
\hline Lantana camara & 22.43 & 34.05 & 36.65 & 36.85 & 36.25 & 35.45 & 38.12 & 43.03 & 42.06 \\
\hline Physalis & 21.10 & 31.10 & 32.65 & 32.26 & 32.55 & 31.32 & 35.17 & 36.55 & 35.48 \\
\hline Melilotus albus & 16.68 & 20.85 & 22.30 & 22.60 & 22.80 & 21.11 & 26.84 & 9.42 & 7.89 \\
\hline Datura stramonium & 18.65 & 20.90 & 22.65 & 22.85 & 22.95 & 21.30 & 18.73 & 10.02 & 8.49 \\
\hline Solanum nigrum & 20.80 & 25.13 & 27.24 & 27.54 & 27.63 & 26.02 & 24.71 & 25.26 & 23.99 \\
\hline Achyranthus aspera & 20.75 & 24.15 & 26.25 & 26.50 & 26.70 & 25.15 & 22.28 & 22.65 & 21.34 \\
\hline Salix sp. & 20.70 & 23.99 & 25.33 & 25.56 & 25.75 & 24.33 & 19.61 & 19.80 & 18.44 \\
\hline Thevetia peruviana & 18.68 & 22.85 & 24.30 & 24.60 & 24.80 & 23.11 & 24.67 & 16.73 & 15.32 \\
\hline Durenta erecta & 20.85 & 26.65 & 28.10 & 28.41 & 28.63 & 27.42 & 27.17 & 27.87 & 26.65 \\
\hline Polyanthia longifolia & 18.60 & 19.05 & 21.46 & 21.55 & 21.65 & 20.85 & 14.08 & 4.61 & 3.00 \\
\hline Control-1 & 17.56 & 18.33 & 20.35 & 20.55 & 20.65 & 19.10 & 14.96 & - & -1.69 \\
\hline Control- 2 & 17.50 & 20.30 & 22.25 & 22.35 & 21.00 & 21.54 & 16.67 & -1.66 & - \\
\hline C.D.P=(0.05) & 1.217 & 1.548 & 1.649 & 1.641 & 1.663 & 1.603 & & & \\
\hline S.E (m) & 0.414 & 0.527 & 0.562 & 0.559 & 0.567 & 0.546 & & & \\
\hline S.E (d) & 0.586 & 0.746 & 0.794 & 0.790 & 0.801 & 0.772 & & & \\
\hline C.V. & 3.618 & 3.678 & 3.667 & 3.671 & 3.666 & 3.669 & & & \\
\hline
\end{tabular}

Table.3 Effect of Plant extracts as inducer on total phenol in potato leaves at different days of intervals after inoculation during

Pathogenesis ( $\mathrm{mg} / \mathrm{g}$ of fresh leaves)

\begin{tabular}{|c|c|c|c|c|c|c|c|c|c|}
\hline \multirow[t]{2}{*}{ Name of inducer } & \multicolumn{6}{|c|}{ Total phenol content at different days of interval (mg/g of fresh leaves) } & \multirow{2}{*}{$\begin{array}{c}\text { Percent increased over, } \\
\text { before application of } \\
\text { inducers }\end{array}$} & \multirow{2}{*}{$\begin{array}{c}\text { Percent increased over } \\
\text { control-1 } \\
\text { (at } 8 \text { days) }\end{array}$} & \multirow{2}{*}{$\begin{array}{c}\text { Percent increased over } \\
\text { control-2 } \\
\text { (at } 8 \text { days) }\end{array}$} \\
\hline & $\begin{array}{c}\text { Before application of } \\
\text { Inducers }\end{array}$ & 2 Days & 4 Days & 6 Days & 8 Days & 10 Days & & & \\
\hline Parthenium hysterophorus & 1.55 & 2.58 & 2.64 & 2.74 & 2.80 & 2.72 & 44.64 & 34.64 & 34.28 \\
\hline Lantana camara & 1.60 & 2.65 & 3.17 & 3.27 & 3.35 & 3.29 & 52.23 & 45.37 & 45.07 \\
\hline Physalis & 1.45 & 1.48 & 2.54 & 2.68 & 2.74 & 2.58 & 47.08 & 33.21 & 32.84 \\
\hline Melilotus albus & 1.12 & 1.16 & 1.24 & 1.53 & 1.98 & 1.67 & 43.44 & 7.57 & 7.07 \\
\hline Datura stramonium & 1.25 & 1.19 & 2.26 & 2.33 & 2.10 & 2.50 & 40.47 & 12.85 & 12.38 \\
\hline Solanum nigrum & 1.40 & 1.35 & 2.42 & 2.50 & 2.63 & 2.53 & 46.76 & 30.41 & 30.03 \\
\hline Achyranthus aspera & 1.36 & 1.26 & 2.36 & 2.40 & 2.43 & 2.49 & 44.03 & 24.69 & 24.27 \\
\hline Salix sp. & 1.30 & 1.24 & 2.34 & 2.41 & 2.35 & 2.50 & 44.68 & 22.12 & 21.70 \\
\hline Thevetia peruviana & 1.27 & 1.22 & 2.29 & 2.36 & 2.30 & 2.45 & 46.78 & 20.43 & 20.00 \\
\hline Durenta erecta & 1.39 & 2.53 & 2.60 & 2.73 & 2.78 & 2.62 & 50.0 & 34.17 & 33.81 \\
\hline Polyanthia longifolia & 1.34 & 1.20 & 2.27 & 2.38 & 2.42 & 2.36 & 44.62 & 24.38 & 23.96 \\
\hline Control-1 & 1.10 & 1.18 & 1.33 & 1.57 & 1.83 & 1.78 & 39.89 & 0.00 & -0.54 \\
\hline Control- 2 & 1.11 & 1.19 & 1.34 & 1.58 & 1.84 & 1.73 & 39.67 & -0.54 & 0.00 \\
\hline C.D.P $=(0.05)$ & 0.083 & 0.103 & 0.139 & 0.143 & 0.149 & 0.150 & & & \\
\hline S.E (m) & 0.028 & 0.035 & 0.047 & 0.049 & 0.051 & 0.051 & & & \\
\hline S.E (d) & 0.040 & 0.050 & 0.067 & 0.069 & 0.072 & 0.072 & & & \\
\hline C.V. & 3.626 & 3.847 & 3.744 & 3.715 & 3.683 & 3.664 & & & \\
\hline
\end{tabular}


Table.4 Correlation of disease severity with total soluble protein and Total phenol content of potato leaves

\begin{tabular}{|c|c|c|c|}
\hline $\begin{array}{c}\text { Biochemical } \\
\text { Parameters }\end{array}$ & $\begin{array}{c}\text { Days after pathogen } \\
\text { inoculation }\end{array}$ & $\begin{array}{c}\text { Correlation coefficient } \\
(\mathbf{r}) \text { with disease severity }\end{array}$ & Regression equation \\
\hline \multirow{2}{*}{$\begin{array}{c}\text { Total soluble } \\
\text { protein }\end{array}$} & 2 Days & -0.3074 & $\mathrm{y}=-0.2609 \mathrm{x}+27.634$ \\
\cline { 2 - 4 } & 6 Days & -0.2560 & $\mathrm{y}=-0.1966 \mathrm{x}+29.774$ \\
\hline \multirow{3}{*}{ Total phenol } & 10 Days & -0.2563 & $\mathrm{y}=-0.1571 \mathrm{x}+28.598$ \\
\cline { 2 - 4 } & 2 Days & -0.1591 & $\mathrm{y}=-0.0221 \mathrm{x}+1.818$ \\
\cline { 2 - 4 } & 6 Days & -0.5608 & $\mathrm{y}=-0.0296 \mathrm{x}+2.8298$ \\
\hline
\end{tabular}

\section{Total phenol content}

The result presented in table 3 shows that all the treatments significantly increased the total phenol content as compared to control-1 and control-2 at 2, 4, 6 and 8 days of pathogen inoculation. The maximum total phenol content was found in Lantana camara treated potato leaves which were $2.65 \mathrm{mg} / \mathrm{g}, 3.17$ $\mathrm{mg} / \mathrm{g}, 3.27 \mathrm{mg} / \mathrm{g}$ and $3.35 \mathrm{mg} / \mathrm{g}$ of fresh leaves at 2, 4, 6 and 8 days of pathogen inoculation, respectively whereas, in case of control-1, the values are $1.18 \mathrm{mg} / \mathrm{g}, 1.33$ $\mathrm{mg} / \mathrm{g}, 1.57$ and $1.83 \mathrm{mg} / \mathrm{g}$ of fresh leave and for control-2, the value are $1.19 \mathrm{mg} / \mathrm{g}, 1.34$ $\mathrm{mg} / \mathrm{g}, 1.58 \mathrm{mg} / \mathrm{g}$ and $1.84 \mathrm{mg} / \mathrm{g}$ of fresh leaves. The Lantana camara treated potato leaves possess increased per cent of total soluble phenol as $45.37 \%$ over control-1 and $45.07 \%$ over control-2 at 8 days of pathogen inoculation. The second highest of total phenol content was found in Parthenium hysterophorus treated potato leaves which were $2.58 \mathrm{mg} / \mathrm{g}, 2.64 \mathrm{mg} / \mathrm{g}, 2.74 \mathrm{mg} / \mathrm{g}$ and $2.80 \mathrm{mg} / \mathrm{g}$ of fresh leaves at 2, 4, 6 and 8 days of pathogen inoculation. The per cent increased of total phenol content at 8 days of pathogen inoculation was of $34.64 \%$ over control-1 and $34.28 \%$ over control-2. The lowest quantity of soluble phenol was harvested in Melilotus albus treated potato leaves, indicating $1.16 \mathrm{mg} / \mathrm{g}, 1.24 \mathrm{mg} / \mathrm{g}, 1.53$ and $1.98 \mathrm{mg} / \mathrm{g}$ of fresh leave at 2, 4, 6 and 8 days. From the table 3 , it is also showed that other treatments like Physalis, Datura stramonium, Solanum nigrum, Achyranthus aspera, Salix sp., Thevetia peruviana, Durenta erecta and Polyanthia longifolia also increased total phenol content over control-1 and contol-2. The total phenol content in potato leaves before and after application of inducing agents clearly indicated that inducing agents have ability to increased total phenol content, representing the value ranges from $17.56-22.43 \mathrm{mg} / \mathrm{g}$ of fresh leave as in before application and 20.65-36.25 mg/g of fresh leave as in after application at $8^{\text {th }}$ days of pathogen inoculation. The highest per cent increased of total phenol before application of plant extracts inducers was found in Lantana camara treated potato leaves which were $52.23 \%$ at maximum 8 days. From the table, it is also cleared that the phenol content in all treated plants increased up to a certain period of time and thereafter, it was decreased gradually. The increased phenol content in treated plants might be due to defense response in plant against $A$. solani. Phenols are well known antifungal, antibacterial and antiviral compounds. The phytoalexins involved in disease resistance are phenolics in chemical constitution. Phenols are involved in disease resistance in many ways like hypersensitive cell death or lignifications of cell walls or increased content of phenol itself toxic also to pathogen (Nicholson and Hammerschimdt 1992). Arzoo et al., (2012) reported that increase content of phenols is associated with defence response in tomato against Fusarium wilt induced by plant 
extract. Girdhari et al., (2008) also reported that increased total phenol content was found in rice leaves after treatment with biotic inducers.

Meena et al., (2001) found that salicylic acid applied as pre-inoculation spray in groundnut plants challenge inoculated with Cercosporidium personatum resulted in three fold increases in phenol content on fourth day. Accumulation of phenolics at the site of infection is a general response of plants in many host- pathogen interactions and this accumulation is fostered by biotic and abiotic elicitors (Farkas and Kiraly, 1962). Retig and Chet (1974) also found a marked accumulation of total phenols when tomato plants were fed with catechol and resulted in suppression of symptom expression due to infection by Fusarium oxysporum f.sp. lycopersici. Therefore, increased content of phenol might be involved in the expression of disease resistance in plant. In the present findings also increased resistance is associated with increased content of soluble protein and total phenol content.

\section{Correlation of disease severity with total soluble protein and total phenol content of potato leaves}

The results presented in table 4 revealed that the leaves treated with plant extracts as inducer decreases disease severity with increased level of soluble protein and total phenol content in potato leaves. The correlation regression equation showed that negative correlation (r) $-0.3074,-0.2560$, 0.2563 was found between total protein with disease severity at 2, 6, 10 days of pathogen inoculation, respectively. The corresponding simple regression equation also showed that increase level of soluble protein has negative role in increase disease development. Similarly, the correlation regression also equation showed that negative correlation (r) -
$0.1591,-0.5608,-0.5495$ between total phenol with disease severity at $2,6,10$ days of pathogen inoculation, respectively.

The corresponding simple regression equation also showed that increase level of total phenol has negative role in increase disease development. Similar observation were also found in rice against brown leaf spot (Kumawat et al., 2010), in tomato against Fusarium wilt (Kumar and Biswas, 2010, Kahkashan Arzoo et al., 2012).

\section{References}

Agrios, G.N. (2005). Plant Pathology. Fifth Edition. Academic Press. California. pp. 922

Anis Rosyidah, Tatik Wardiyati, Abdul Latief Abadi, M. Dawam Maghfoer, Luqman Qurata Aini (2014). Induced resistance of Potato (Solanum tuberosum L.) toward Ralstonia solanacearum disease with combination of several bio-control microbes; Journal of Biology, Agriculture and Healthcare, 4(2): 90-98

Antoniw, J.F., Ritter, C.E., Pierpoint, W.S., Van Loon, L.C., (1980). Comparison of three pathogenesis related proteins from plants of two cultivars of tobacco infected with TMV. J Gen Virol, 47: 79-87.

Biswas, S.K., Srivastava, K.D., Aggarwal, R., Shelly, P., Singh, D.V., (2003). Biochemical changes in wheat induced by Chaetomium globosum against spot blotch pathogen. Indian Phytopath. 54(4):374-379.

Boller, T., (1985). Induction of hydrolases as a defense reaction against pathogens. In: Cellular and molecular biology of plant stress, (Eds., Key, J.L. and Kosuge, T.), UCLA Symposia on Molecular and Cellular Biology, New Series, Volume 22, Alan R. Liss, Inc., New York. pp. 247-262. 
Bray, H.C., Thorpe W.V., (1954). Analysis of phenolic compound of interest in metabolism. Plant Biochem. 1:27-52.

Campo, A.R.O., Zambolim, L. Vale, F.X.R., Costae, L.C. Martyinez, C.A. (2001). Efeito da pinta preta (Alternaria solani) no crescimento e produção da batata (Solanum tuberosum L.). Fitopatol. Bras. Suppl. 26:450.

Chairul. (2003). Rapid identification of bioactive materials in plants in the field. (In Indonesia). Berita Biologi 6(4): 621628

Cohen, Y., Niderman, T., Mosinger, E. \& Fluhr, R., (1994). Beta-Aminobutyric acid induces the accumulation of pathogenesis-related proteins in tomato (Lycopersicon esculentum L.) plants and resistance to late blight infection caused by Phytophthora infestans. Plant Physiology (Rockville) 104(1), 59-66.

D. K. Sahu, C. P. Khare, H. K. Singh and M. P. Thakur (2013). Evaluation of Newer Fungicide for Management of Early Blight of Tomato in Chhattisgarh, The bioscan, 8(4): 1255-1259, 2013

Farkas, G., and Kiraly, J., (1962). Role of phenolic com-pounds in the physiology of plant disease and disease resistance. Phytopathological Zoology, 44: 105150.

Girdhari, L.K., Biswas, S.K., Srivastava, S.S.L., (2008). Biochemical evidence of defense response in paddy induced by bio-agents against brown leaf spot pathogen. Indian Phytopath. 61(2):197203.

Gozzo F (2003) Systemic acquired resistance in crop protection: from nature to a chemical approach. J Agric Food Chem. 51: 4487-4503.

Gudmestad N. C., Pasche J. S. (2007). Role of fenamidone in the management of potato early blight-Alternaria solani. Proceedings of the 10th workshop of a European network for development of an integrated control strategy of potato late blight. PPO-Special Report No. 12. Bologna, Italy, p. 175-182

Jahanshir Amini (2015). Induced resistance in potato plants against verticillium wilt invoked by chitosan and Acibenzolar-Smethyl, AJCS 9(6):570-576

Johnson, K.B. and Teng, P.S. (1990). Coupling a disease progress model for early-blight to model of potato growth. Phytopathol. 80(4): 416-425.

Kahkashan Arzoo, Samir Kumar Biswas and Mohd. Rajik, (2012). Biochemical Evidences of Defence Response in Tomato against Fusarium Wilt Induced by Plant Extracts. Plant Pathology Journal, 11: 42-50.

Kumar, A., Biswas, S.K., (2010). Biochemical evidence of induced resistance in tomato against Fusarium wilt through inorganic chemicals. $J$. Mycopathol. Res. 48(2): 213-219.

Kumawat, G.L., Biswas, S.K., Mohd, R., (2010). Antagonistic evaluation of Trichoderma spp. and there effect of on seed germination and growth of paddy seedling. J. Plant Dis. Sci. pp. 203-207.

Lowary, H.O., Rosebrough, N.J., Farr, A.L., Randall, R.J., (1951). Protein measurements with folin phenol reagent. J. Biol. Chem. 193: 265-275.

Malolepsza U (2006) Induction of disease resistance by acibenzolar-S-methyl and $O$ - hydroxyethylorutin against Botrytis cinerea in tomato plants. Crop Prot. 25: 956-962.

Metraux, J.P., Streit, L., Staub, T., (1988). A pathogenesis related protein in cucumber is a chitinase. Physiol. Mol. Plant Pathol. 33:1-9.

Nashwa S.M.A., Abo-Elyousr K.A.M. (2012): Evaluation of various plant extracts against the early blight disease of tomato plants under greenhouse and field conditions. Plant Protect. Sci., 48: 74-79. 
Nicholson, R.L., Hammerschmidt, R., (1992). Phenolic compounds and their role in disease resistance. Annual Review of Phytopathology, 30:369-389.

Retig, N., Chet, I., (1974). Catechol induced resistance of tomato plants to Fusarium wilt. Physiology and Plant Pathology, 4: 496-475.

Rotem, J. (1981). Fungal diseases of potato and tomato in the Negev region. Plant Dis. 65(4):315-318.

Rowe, R.C., Miller S.A. and Riede R.M. (Undated). Early Blight of Potato and Tomato. FactSheet, Plant Pathology, 2021 Coffey Road, Columbus, OH 43210-1087.

Shtienberg, D., D. Blachinsky, G. BenHador, and Dinoor, A. (1996). Effects of growing season and fungicide type on the development of Alternaria solani and on potato yield. Plant Dis. 80(9): 994-998.

Sindhan, G.S., Parashar, R.D., (1996). Biochemical changes induced by Cercospora leaf spots in groundnut (Arachus hypogea L.) Indian J. Mycol. Pl. Path., 26: 210-212.

Steiner, U.; Schönbeck, F., (1995). Induced Disease Resistance In Monocots. In: Hammerschmidt, R.; Kuc, J. (Ed.).Induced resistance to disease in plants: developments in plant pathology. Dordrech: Kluwer Academic
Pub. P.235-270.

Thanassoulopoulos CC, Hooker WJ (1968) Factors influencing infection of field grown potato by Verticillium alboatrum. Am Potato J. 45: 203-216?

Tuzun, S, Rao, M.N., Vogeli, U., Scharde, C.H., Kuc, J., (1989). Induction of systemic resistance to blue mold: Early induction and accumulation of $\beta-1,3-$ glucanases, chitinases and other pathogenesis related proteins (PRproteins) in immunized tobacco. Phytopathol 79: 979-983.

Uppal AK, hadrami AE, Adam LR, Tenuta M, Daayf F (2008) Biological control of potato Verticillium wilt under controlled and field conditions using selected bacterial antagonists and plant extracts. Biological Control. 44: 90100.

Waals, J.E., Korsten L., Slippers, B. (2004). Genetic diversity among Alternaria solani isolates from potatoes in South Africa. Plant Dis. 88: 959-964.

Www. National Horticulture database, 2015

Www. Wikipedia, the free encyclopedia.

Yusuf Yanar, Ayhan Gökçe1, Izzet Kadioglu1, Halit Çam1 and Mark Whalon (2011) In vitro antifungal evaluation of various plant extracts against early blight disease (Alternaria solani) of potato, African Journal of Biotechnology., 10(42): 8291-8295.

\section{How to cite this article:}

Virendra Kumar, S.K. Biswas, Kishan Lal, Devash Nagar and Tilak Chowdary, V. 2017. Induced Resistance in Potato against Early Blight Caused by Alternaria solani (Sorauer) Through Plant Extracts as Inducer. Int.J.Curr.Microbiol.App.Sci. 6(8): 1888-1898. doi: https://doi.org/10.20546/ijcmas.2017.608.223 